\title{
Isolation by distance and stochastic migration in a fragmented population of Prosopis alba ${ }^{1}$
}

\author{
Leandro G. Roser ${ }^{2,5}$, Laura I. Ferreyra², Mauricio Ewens ${ }^{3}$, Juan C. Vilardi ${ }^{4}$, and Beatriz O. Saidman ${ }^{2}$
}

\begin{abstract}
PREMISE OF THE STUDY: Gene flow through dispersal of seeds and pollen is a fundamental determinant of spatial genetic structure (SGS) in natural populations of trees at different spatial scales. Within continuous populations, restrictions to gene flow should be manifested in a process of local genetic differentiation, known as isolation by distance. The present work examines the SGS of a Prosopis alba population in a patchy region where urban, forest, and agricultural areas coexist. The analysis discussed here expands our knowledge about the processes affecting the distribution of the genetic variability in populations of disturbed landscapes.
\end{abstract}

METHODS: Three sites with different landscape and demographic characteristics were analyzed. Seven highly variable microsatellite markers were used to survey the relevance of both isolation by distance and stochastic migration in the SGS of the population.

KEY RESULTS: The analyses showed that (1) the genetic similarity declined with increasing geographic distance, (2) the population may be conceived as a single genetically continuous unit showing spatial differentiation as consequence of isolation by distance, rather than a structured population following the island model, and (3) there is evidence supporting a past immigration event into one of the study sites, which promoted a local pattern of genetic structure.

CONCLUSIONS: These results indicate that in spite of the population fragmentation produced by land-use changes, $P$. alba maintains the genetic cohesion and a continuous genetic structure in the analyzed area.

KEY WORDS Fabaceae; isolation by distance; kinship; landscape genetics; microsatellites; Prosopis alba; spatial genetic structure; stochastic migration

Spatial genetic structure (SGS) can be defined as the nonrandom distribution of genotypes in a given space (Vekemans and Hardy, 2004) and is a consequence of a complex combination of processes acting at different scales. In trees, gene flow is mediated by mobile structures with reproductive function as seeds, pollen, and vegetative propagules, while the adult stage is sessile. When the dispersal

\footnotetext{
Manuscript received 8 June 2016; revision accepted 21 December 2016.

${ }^{2}$ Universidad de Buenos Aires, Consejo Nacional de lnvestigaciones Científicas y Técnicas, Instituto de Ecología, Genética y Evolución (IEGEBA), Facultad de Ciencias Exactas y Naturales, Departamento Ecología, Genética y Evolución, Genética de Especies Leñosas (GEEL), 1428, Buenos Aires, Argentina;

${ }^{3}$ Estación Experimental Fernández, Universidad Católica de Santiago del Estero, 4200, Santiago del Estero, Argentina; and

${ }^{4}$ Universidad de Buenos Aires, Consejo Nacional de lnvestigaciones Científicas y Técnicas, Instituto de Ecología, Genética y Evolución (IEGEBA), Facultad de Ciencias Exactas y Naturales. Departamento Ecología, Genética y Evolución, Genética de Poblaciones Aplicada (GPA), 1428, Buenos Aires, Argentina

${ }^{5}$ Author for correspondence (e-mail: learoser@gmail.com); present address: Instituto de Investigaciones Biotecnológicas (IIB-INTECH), Universidad Nacional de San Martín, 1650, Buenos Aires, Argentina

doi:10.3732/ajb.1600221
}

distance of seeds and/or pollen is limited, individuals will mate within a restricted neighborhood, rather than mating with other, more distant members of their population (Sokal and Wartenberg, 1983), a process known as isolation by distance (IBD, Wright, 1943). The action of this process over time will produce a particular genetic structure (isolation by distance pattern) consisting of decreasing relatedness of individuals with increasing geographical distance (Malécot, 1948, 1959; Morton et al., 1968; Loiselle et al., 1995).

In addition to IBD, multiple factors may influence the distribution of genetic diversity within populations, including mating system (Vekemans and Hardy, 2004), adult population density (Hamrick et al., 1993), microhabitat selection (Levin and Kerster, 1974; Epperson, 1993), demographic structure (Chung et al., 2003), and historical events, such as disturbance and colonization (Parker et al., 2001; Premoli and Kitzberger, 2005; Pardini and Hamrick, 2008). Natural populations can be affected by a combination of several factors, and it is of interest for population geneticists to elucidate their relevance when a pattern of SGS is observed. Estimating SGS parameters in plants allows an understanding of ecological 
and evolutionary population changes over time and provides key information to assist in programs of genetic resource management, e.g., in the design of seed collection strategies for ex-situ conservation (Finkeldey and Mátyás, 2003).

Prosopis alba Griseb. (Fabaceae) is an important woody species native to South America, present in Argentina, Uruguay, Paraguay, Bolivia, Chile, and Peru. It is a medium-size tree, widely distributed in the Dry Chaco region (Fig. 1A), a vast sedimentary plain shaped by the action of rivers running in a NW-SE direction (Torrella and Adámoli, 2005). The species has an important role in the ecosystem, contributing to increased soil fertility by fixing atmospheric nitrogen (Pasiecznik et al., 2001). Forests of $P$. alba originally extended over hundreds of kilometers, but they became degraded and fragmented mainly in the last century by extractive exploitation of forest resources and unsustainable use of lands (Adámoli et al., 1990). In recent times, environmental degradation in the region has accelerated as the agricultural frontier has expanded (Gasparri and Grau, 2009). As a result of the pioneer habit of $P$. alba, recolonization of disturbed areas is an important factor affecting its spatial distribution. Previous works have reported high genetic variability

A

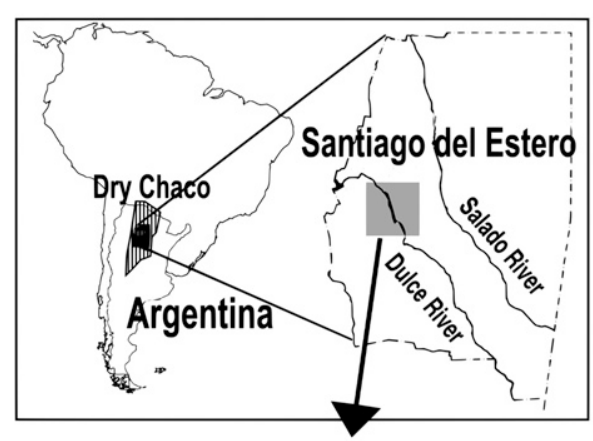

B

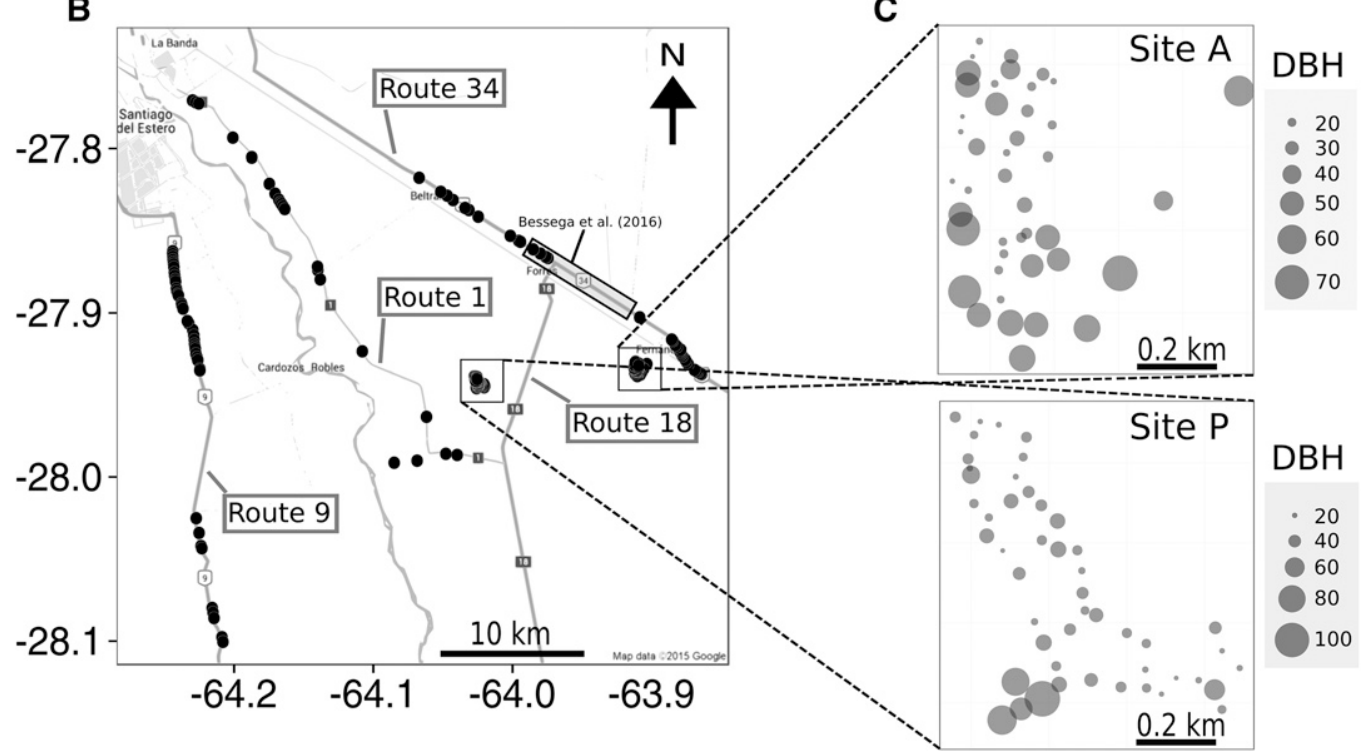

FIGURE 1 Distribution of Prosopis alba individuals sampled in Santiago del Estero Province, Argentina. (A) Localization of the analyzed landscape in South America. The striped area indicates the Dry Chaco region. (B) Localization of sampled trees in sites $A, P$, and $R$. Site $R$ includes individuals located on both sides of the National Routes 1, 9, and 34. The collection site of Bessega et al. (2016) along Route 34 is represented with a rectangle. (C) Detail of sites A and P. The size of the circles (samples) is proportional to the diameter at breast height (DBH), as indicated in the legends. in this species, mostly present within populations (Ferreyra et al., 2004, 2007, 2013; Bessega et al., 2012). Both seed and pollen dispersal are mediated by animals and take place over relatively short distances (Reynolds, 1954; Mares et al., 1977; Genise et al., 1990; Bessega et al., 2012). Livestock tend to eat as many fruits as possible from a single mother plant, depositing the scarified seeds in dung, which promotes the aggregation of full- and half-sib seeds in narrow areas (Steibel and Troiani, 1999; Bessega et al., 2012). Pollen is transported by insects at an average distance of 5 to $30 \mathrm{~m}$ (Bessega et al., 2012). Prosopsis alba is predominantly outcrossed, with a proportion of biparental inbreeding low but significantly higher than zero (Bessega et al., 2000, 2012).

A recent paper (Bessega et al., 2016) compared the fine-scale SGS between two geographically isolated samples of $P$. alba in Argentina, collected from areas with different levels of disturbance, at Campo Duran and Fernández-Forres (provinces of Salta and Santiago del Estero, respectively). The first sample was composed of trees located in corridors and semiurban areas, while the second included trees of about the same age disposed along a corridor (transect following Route 34). The authors found positive and significant SGS at short distances only in the nondisturbed sample (Campo Duran) and concluded that disturbance may affect effective neighborhood size and dispersal ability. This previous study raised questions about the patterns of SGS in the area where the Fernández-Forres corridor (shown in Fig. 1B) is located, considering now a higher scale of analysis (landscape). At the landscape level, the area can be characterized geologically as an alluvial fan, where anthropogenic activities have strongly affected the distribution of $P$. alba, creating an heterogeneous, patchy habitat, with land-use changes.

The present work evaluates the SGS and its dynamics within a population of $P$. alba at the landscape level, considering factors such as habitat heterogeneity, demographic structure and historical events. For this purpose, the research includes samples from patches and corridors, products of different historical processes; individuals of varying ages; and a wide spatial range. The relevance of both isolation by distance and stochastic migration events was examined with microsatellite data. The consequences of these processes in $P$. alba forests are discussed in terms of their possible effects on the genetic variability and SGS in fragmented populations. 


\section{MATERIALS AND METHODS}

Sampling-The study area is located in the Santiago del Estero Province, Argentina $\left(27.84^{\circ} \mathrm{S}, 64.18^{\circ} \mathrm{W}\right)$, within the Dry Chaco region (Fig. 1A). It presents a hot, arid steppe climate (Kottek et al., 2006) and a heterogeneous microtopography, with patches varying in fertility, salinity, and texture (Arístide, 2010). Agricultural and pastoral activities on the basins of the two main rivers that flow through the province (Dulce and Salado rivers, Fig. 1A) have undergone important historic development from prehispanic times to the present. The landscape analyzed (Fig. 1B) involves a mosaic of intermixed urban, forest, and agricultural areas. Sampling was designed to obtain a representative picture of the area, to quantify the SGS over different spatial scales, from a single patch to the whole landscape. A sample of $N=186$ trees (Appendix 1) distributed in three sites (A, P, and $\mathrm{R}$ ) was studied. It is assumed that these individuals represent a sample of a single, fragmented population extending beyond the study area. The three sampling sites have different historical and ecological characteristics. Sites A $(N=43)$ and $\mathrm{P}(N=50)$ represent repopulation of former agricultural zones, which are currently not in use (Fig. 1C). Although precise historical information is lacking, the recolonization in site $\mathrm{P}$ was not managed, yielding a closed tree cover. In contrast, tree cover is open in site $A$, as a result of human management (i.e., vegetation clearing and thinning). Site $\mathrm{R}(N=93)$ includes trees located on both sides of three roads (National Routes 1, 9, and 34, Fig. 1B). This area represents corridors with a sparse tree cover, consisting of remnants of the ancient, wide and dense forest and also of trees established after human disturbance. For comparative purposes, the location of the sample analyzed by Bessega et al. (2016) on National Route 34 is shown in Fig. 1B.

The diameter at breast height $(\mathrm{DBH})$ of each individual was measured with a diameter tape to the nearest millimeter. $\mathrm{DBH}$ values were used as a raw estimate of tree age. Only individuals with $\mathrm{DBH}$ larger than $11 \mathrm{~cm}$ were included in this study.

DNA analysis-Young leaves of the 186 individuals were collected and preserved in silica-gel at room temperature. DNA was extracted using a DNeasy Plant Mini Kit (Qiagen, Valencia, California, USA), and samples were placed in $\mathrm{a}-20^{\circ} \mathrm{C}$ freezer until analysis. In the present work, we analyzed seven microsatellite loci, four developed by Mottura et al. (2005): Mo05 (CT) ${ }_{3} \mathrm{~T}(\mathrm{CT})_{2}, \mathrm{Mo07}(\mathrm{GC})_{8}, \mathrm{Mo09}$ $(\mathrm{TG})_{17}$, and $\operatorname{Mol} 13(\mathrm{GT})_{10} \mathrm{CT}(\mathrm{GT})_{2}$; and three by Bessega et al. (2013): GL12 (CT) ${ }_{5}(\mathrm{ATCT})_{3}(\mathrm{CT})_{5}$, GL24 (AC) $)_{11}$, and GL26 (GT) The number of SSR markers used is expected to be adequate for SGS analysis on the basis of the survey by Bessega et al. (2016). These authors observed that four of the microsatellite loci so far developed for $P$. alba and related species are enough to recognize more than $90 \%$ of the multilocus genotypes and that the utilization of at least only five loci allows the recognition of single individuals in population samples from Santiago del Estero and Salta Provinces (Argentina). PCR amplifications and electrophoretic analyses were conducted as described previously by Roser et al. (2014). Individuals that after several amplifications did not show a product at a particular locus (varying the DNA concentration and annealing temperature and including a re-extraction and amplification step), were coded as homozygotes for a null allele.

Statistical analyses-The frequency of null alleles was estimated for each locus by means of the EM algorithm (Dempster et al.,
1977) in the program GENEPOP 4.5 (Rousset, 2008). Linkage disequilibrium was evaluated for all possible pairs of loci using a $G$ test (Sokal and Rohlf, 1981), which applies a Markov chain Monte Carlo (MCMC) method. Both analyses were performed for the total sample of 186 individuals in GENEPOP 4.5 (Rousset, 2008). For the $G$ test, matrix-wide significance values of individual tests were obtained applying the false discovery rate correction for multiple comparisons of Benjamini and Hochberg (1995) using the package stats of R 3.1.2 (R Core Team, 2014).

Genetic diversity-Observed $\left(H_{\mathrm{o}}\right)$ and expected heterozygosity $\left(H_{\mathrm{E}}\right)$ under Hardy-Weinberg equilibrium were calculated for each locus and averaged over loci using an unbiased estimator (Nei and Chesser, 1983) with the package Hierfstat 0.04-14 (Goudet, 2005) of R. Allelic richness $\left(A_{\mathrm{r}}\right)$, an expected count of the total number of alleles (considering all loci) in a sample in reference to a given sampling size (Kalinowski, 2004), was computed for each individual site (A, P, and R) using the size of the smallest sample $(N=43) . A_{\mathrm{r}}$ values and their confidence intervals (CIs) were estimated with the package ARES 1.2-3 (Van Loon et al., 2007), in a version actualized to R 3.1.2 by Leandro Roser (available at https://github.com/leandroroser/Ares_1.2-4). The mean allelic richness per locus $\left(\bar{A}_{\mathrm{r}}\right)$ was obtained as $A_{\mathrm{r}} / L$, were $L=7$ is the number of analyzed loci.

Spatial genetic structure analysis-The SGS of the population was analyzed with $F$ statistics (Wright, 1951), according to the method of Weir and Cockerham (1984). The three sites (A, P, and R) (Fig. 1B, C) were considered as different samples, computing the values of $F_{\text {IS }}$ (global and per site), and $F_{\text {ST }}$. The $F_{\text {IS }}$ statistics were estimated with the package diveRsity 1.9.73 (Keenan et al., 2013) in R. Confidence intervals of $95 \%$ were constructed by bootstrap with 10,000 replicates over individuals and loci, considering the estimates significant when the intervals did not overlap zero. $F_{\mathrm{ST}}$ and its significance, obtained by a randomization test with 10,000 permutations, were computed with the package Hierfstat.

Total variation among individuals was partitioned into among sites, within sites and within individuals (heterozygosity) by AMOVA (Michalakis and Excoffier, 1996) with the package poppr 1.1.4 (Kamvar et al., 2014) in R. The significance levels of $\Phi$ statistics were obtained by a Monte Carlo test with 10,000 permutations.

The existence of spatial structure was analyzed with the program STRUCTURe 2.3.4 (Pritchard et al., 2000). An admixture model with correlated allele frequencies (Falush et al., 2003) was used, allowing the number of genetic clusters $(K)$ to vary between 1 and 10 . For each run, 500,000 MCMC repetitions with a burn-in length of 100,000 steps were used. A total of 10 independent runs were completed for each value of $K$. Optimal $K$ values were determined with STRUCTURE HARVESTER (Earl and vonHoldt, 2012) by comparing the average log-likelihood of data for each value of $K$ (Pritchard et al., 2000 ), and by the $\Delta K$ statistic (Evanno et al., 2005), based on the second order rate of change in the log-likelihood of data between successive $K$ values.

Kinship analysis - Within-population SGS can be characterized using several autocorrelation methods based on the relation between kinship estimates for pairs of individuals and the geographical distance separating them (Loiselle et al., 1995; Smouse and Peakall, 1999; Rousset, 2000; Vekemans and Hardy, 2004). A kinship matrix 
was obtained using the Nason's kinship coefficient $f_{i j}$ (Loiselle et al., 1995; Kalisz et al., 2001), estimated for each locus and allele following Heuertz et al. (2003):

$$
f_{i j}(a l)=\frac{\sum_{i} \sum_{j}\left(p_{i a l}-\bar{p}_{a l}\right)\left(p_{j a l}-\bar{p}_{a l}\right)}{\bar{p}_{a l}\left(1-\bar{p}_{a l}\right)}+\frac{1}{2(N-1)},
$$

where $\bar{p}_{a l}$ is the population frequency of the ath allele of the lth locus, $p_{i a l}$ and $p_{\text {jal }}$ are the frequencies of the same allele in the $i$ th and $j$ th individuals, respectively, and $N$ is the sample size. In each individual, the possible $p_{i a l}$ values correspond to the proportion of copies of the ath allele in its genotype (that is, $0,0.5$, or 1 ). The expression above shows that $f_{i j}$ is basically a correlation coefficient (first term) with a correction for sample size (second term) (Fenster et al., 2003). The multilocus coefficient was obtained by weighting the $f_{i j}$ for each allele $a$ by its polymorphism index $\left[\bar{p}_{a l}\left(1-\bar{p}_{a l}\right)\right]$ as defined by Heuertz et al. (2003).

To visualize SGS, we constructed a spatial genetic correlogram using nine distance classes $(d)$ in the range $0-900 \mathrm{~m}$, with 250 pairwise comparisons per class. The number of classes were selected following the suggestion of Hardy and Vekemans (2015) to include a minimum of 100 pairs of individuals per class; the cut-off distance was determined on the basis of a preliminary inspection of the correlogram, which showed a decreasing spatial autocorrelation for interindividual distances below $900 \mathrm{~m}$, and a fluctuation around $f_{i j}=0$ for larger distances. The values of $f_{i j}$ were averaged within each class to obtain $f(d)$, the dependent variable of the correlogram. Confidence intervals of $95 \%$ were computed for $f(d)$, using 10,000 random permutations of individuals among geographical locations (Loiselle et al., 1995; Kalisz et al., 2001; Vekemans and Hardy, 2004). To test SGS, the values of $f_{i j}$ were regressed on $\ln d_{i j}$ (where $d_{i j}$ is the physical distance between individuals $i$ and $j$ ) in the range 0-900 $\mathrm{m}$, to provide the slope $(b)$, as suggested by Vekemans and Hardy (2004). Standard errors of $b\left(\mathrm{SE}_{b}\right)$ and of the kinship value for the first distance class $\left(f_{(1)}\right)(<91 \mathrm{~m})$, were obtained by jackknife across loci (Vekemans and Hardy, 2004; Hardy et al., 2006).

The null hypothesis of absence of SGS was evaluated by a Mantel test between $f_{i j}$ and $\ln d_{i j}$ (Rousset, 1997; Vekemans and Hardy, 2004) with 10,000 replicates. SGS intensity was quantified with the $S p$ statistic of Vekemans and Hardy (2004), defined as:

$$
S p=\frac{b}{1-f_{(1)}}
$$

Following Hardy et al. (2006), an approximated 95\% CI for Sp was estimated as:

$$
\mathrm{CI}_{S p}=\frac{b \pm t_{(N-1,0.975)} \mathrm{SE}_{b}}{1-f_{(1)}}
$$

The upper part of the term is the CI of $b$, where $t$ is the two-tailed critical value for the Student's $t$ distribution with $N-1$ degrees of freedom and $\alpha=0.05$. These analyses were conducted in $\mathrm{R}$ with the package EcoGenetics 1.2.0-3 (Roser et al., 2015).
Demographic analyses-To characterize the distribution of tree diameter within each site, we plotted and visually inspected the histograms for $\mathrm{DBH}$. For a quantitative approach, a mixture model analysis was performed with the package mclust 5.1 (Fraley and Raftery, 2002) in R. The analysis consisted of the decomposition of the empirical distribution of $\mathrm{DBH}$ in an optimum number of Gaussian components $(\geq 1)$. The program was run from 1 to 6 components, for the models " $E$ " (components with equal variance) and " $V$ " (components with variable variance). For each site, the best model was selected as the one with the smallest value of Bayesian information criterion (BIC).

The presence of genetic structure due to processes of recent colonization was evaluated taking into account the allometric correlation between $\mathrm{DBH}$ and tree age, assuming that the higher the $\mathrm{DBH}$, the older the $P$. alba tree (see Giménez et al., 2001, and Juárez de Galíndez et al., 2005). The samples from sites A, P, and R were divided into diameter classes using a double criterion. If the outcome of the mixture model analysis for a sample consisted of two or more groups, this classification was assigned to the corresponding site. On the contrary, when only a single group was detected, the corresponding sample was divided into the highest number of contiguous classes including at least 18 individuals each. The differentiation of individual multiallele genotypes among DBH classes within sites was analyzed by discriminant analysis. The significance was evaluated by a Monte Carlo test with 10,000 replicates. The analysis was conducted with the package ade4 1.7-2 (Chessel et al., 2004; Dray and Dufour, 2007) of R. For each class, the allelic richness and its CI were obtained with the package ARES, for a rarefacted sample size of 18 individuals.

\section{RESULTS}

Genetic diversity-The seven analyzed loci were polymorphic, with 5-10 alleles each and an average number of 6.3 alleles per locus (Table 1). Allelic richness analysis indicated significant differences only between sites A and R (non-overlapping CIs), with the former having fewer alleles under rarefaction (Table 1).

Homozygotes for null alleles were detected for the loci GL12, GL24, GL26, and Mo13. The EM algorithm estimated null allele frequencies smaller than 0.11 for all the loci with the exception of Mo07, with a value of 0.14 . In no case was any evidence of pairwise linkage disequilibrium found according to the pairwise $G$ tests.

Genetic structure analyses-An excess of homozygotes was observed for both the whole population $\left(F_{\text {IS }}=0.13\right)$ and within sites A,

TABLE 1. Genetic diversity values for the whole population of Prosopis alba and each sampling site $(\mathrm{A}, \mathrm{P}, \mathrm{R})$. Different letters after $A_{r}$ values indicate that the corresponding confidence intervals do not overlap. The population value for $A_{r}$ is the count of the actual number of alleles present in the whole sample $(N=186)$ (without correction for sampling size).

\begin{tabular}{lcclr}
\hline Sample & $\boldsymbol{H}_{\mathrm{O}}$ & $\boldsymbol{H}_{\mathrm{E}}$ & \multicolumn{1}{c}{$\boldsymbol{A}_{\boldsymbol{r}}$} & $\overline{\boldsymbol{A}}_{\mathbf{r}}$ \\
\hline Site A & 0.40 & 0.46 & $36.00 \mathrm{a}$ & 5.14 \\
Site P & 0.50 & 0.57 & $40.10 \mathrm{a}, \mathrm{b}$ & 5.73 \\
Site R & 0.47 & 0.54 & $39.81 \mathrm{~b}$ & 5.69 \\
Population & 0.46 & 0.57 & 44 & 6.28 \\
\hline
\end{tabular}

Notes: $H_{0}$ observed heterozygosity, $H_{E}$ expected heterozygosity, $A_{\mathrm{r}}$ allelic richness, $\bar{A}_{\mathrm{r}}$ mean allelic richness per locus. 
$\mathrm{P}$, and $\mathrm{R}$ (Table 2). However, a deficiency of homozygotes was observed in some cases for individual loci (Table 2). The global value of $F_{\mathrm{ST}}$ was low but significant $\left(F_{\mathrm{ST}}=0.01, P<0.01\right)$, suggesting genetic differentiation among the considered sites. The results of AMOVA showed that the highest proportion of genetic variation is contained within individuals; of the remaining variation, most is explained by the between individuals within sites component, and a minor proportion by the among sites component (Table 3). AMOVA $(\Phi)$ coefficients were congruent with the global values of $F_{\text {IS }}$ and $F_{\text {ST }}$ (Table 3 ).

The analysis conducted with STRUCTURE indicated that the $K$ value with the highest $\log$-likelihood after 10 runs was $K=1$. Although $\Delta K$ statistic is not applicable to test whether $K=1$ is an optimum solution, the result gave no evidence to reject the hypothesis that the whole sample corresponds to a single, genetically continuous population.

Kinship analysis - In agreement with models of isolation by distance, kinship analysis showed a decreasing trend in the values of $f_{i}$ with the geographical distance, evidenced by the correlogram of Fig. 2. The autocorrelation was significant for the first distance class $\left(f_{i j}=0.0347, \mathrm{CI}=[0.0140,0.0561]\right)$ and showed a decreasing trend for the following classes. The regression slope of $f_{i j}$ on $\ln d_{i j}$ was significant $(b=-0.0072 ; P<0.05 ; \mathrm{CI}=[-0.0146,-0.0003])$, yielding an $S p$ statistic of $0.0074(\mathrm{CI}=[0.0003,0.0150])$.

Demographic analysis-The histograms representing the distribution of DBH for each site (Fig. 3) suggested the presence of a bimodal distribution in site A. Mixture model analysis for this site showed the lowest value of BIC for a solution with two components (bimodal distribution, Fig. 3) with equal variances $\left(\right.$ mean $_{\mathrm{A} 1}=21.7$, mean $_{\mathrm{A} 2}=53.8, \mathrm{SD}_{\mathrm{Al}, 2}=7.8$ ). The intersection between the two distributions corresponds to a diameter value of around $37 \mathrm{~cm}$ (Fig. 3 ). The analysis for the other two sites determined a unique component (unimodal distribution, Fig. 3) as the solution with the lowest value of BIC $\left(\operatorname{mean}_{\mathrm{P}}=34.9, \mathrm{SD}_{\mathrm{P}}=11.2 ;\right.$ mean $\left._{\mathrm{R}}=55, \mathrm{SD}_{\mathrm{R}}=14.2\right)$. For the allelic richness and discriminant analyses, in site A two diametric classes were considered: individuals with $\mathrm{DBH}$ less (1) and greater (2) than $37 \mathrm{~cm}$. This criterion was based on the outcome of the mixture model analysis. As for the other sites, the analysis identified a single diametric distribution, the criterion used to split the samples in groups was based on the highest number of classes with at least 18 individuals, as described in the Materials and Methods. In site $\mathrm{P}$, two diametric classes were considered: individuals with $\mathrm{DBH}$ less (1) and greater (2) than $37 \mathrm{~cm}$. In site R, 4 classes were considered: less than 44 (1), between 44 and 53 (2), between 53 and

TABLE 2. Inbreeding coefficients $\left(F_{15}\right)$ for the whole analyzed population of Prosopis alba and each sampling site (A, P, R). Asterisks indicate $F_{\text {IS }}$ estimates differ significantly from zero.

\begin{tabular}{lcccc}
\hline & & \multicolumn{3}{c}{ Site } \\
\cline { 3 - 5 } Locus & Population & $\mathbf{A}$ & $\mathbf{P}$ & $\mathbf{R}$ \\
\hline Mo05 & 0.004 & 0.297 & $-0.095^{*}$ & -0.046 \\
Mo07 & $0.127^{*}$ & 0.014 & 0.154 & 0.138 \\
Mo09 & 0.000 & $-0.087^{*}$ & 0.033 & 0.013 \\
Mo13 & $0.145^{*}$ & 0.100 & 0.114 & $0.176^{*}$ \\
GL12 & 0.052 & -0.134 & 0.055 & 0.112 \\
GL24 & $0.200^{*}$ & $0.483^{*}$ & $0.170^{*}$ & 0.068 \\
GL26 & $0.234^{*}$ & -0.061 & 0.157 & $0.353^{*}$ \\
Global & $0.130^{*}$ & $0.100^{*}$ & $0.110^{*}$ & $0.127^{*}$ \\
\hline
\end{tabular}

TABLE 3. Analysis of molecular variance (AMOVA) for the analyzed population of Prosopis alba. All $\Phi$ values were significant $(P=0.001)$.

\begin{tabular}{lrrc}
\hline Variation source & df & vc (\%) & $\boldsymbol{\Phi}$ \\
\hline Between sites $\left(\Phi_{\text {ST }}\right)$ & 2 & 1.43 & 0.01 \\
Between individuals within sites $\left(\Phi_{15}\right)$ & 183 & 12.29 & 0.12 \\
Within individuals & 186 & 86.28 & - \\
Total & 371 & 100 & - \\
\hline
\end{tabular}

Notes: df, degrees of freedom, vc, variance components, $\Phi$, AMOVA $\Phi$ coefficients.

61 (3), and greater than $61 \mathrm{~cm} \mathrm{(4).} \mathrm{For} \mathrm{each} \mathrm{diametric} \mathrm{class} \mathrm{and} \mathrm{site,}$ the allelic richness $\left(A_{\mathrm{r}}\right)$ was estimated for a sampling size $N=18$ (Fig. 4). The comparison among diameter classes evidenced the lowest value of $A_{\mathrm{r}}$ for the sample of individuals with the smaller diameter in site A (A1). The CI of this estimate does not overlap with the CIs obtained for the individuals with smaller diameter in sites P (P1) and R (R1) (Fig. 4). The rest of $A_{\mathrm{r}}$ estimates showed overlapping CIs (Fig. 4). Discriminant analysis of multilocus genotypes (Fig. 5) showed that the diameter classes are clearly differentiated within site $\mathrm{A}(P<0.02)$. This trend, however, was not observed in sites $\mathrm{P}$ or $\mathrm{R}(P>0.05)$.

\section{DISCUSSION}

The seven microsatellite loci analyzed in this paper showed high levels of genetic diversity $\left(H_{\mathrm{O}}=0.46\right.$ and $\left.H_{\mathrm{E}}=0.57\right)$ as reported in other studies of $P$. alba (Bessega et al., 2012, 2015). The general excess of homozygotes observed for most loci is also consistent with the results of previous works, where different molecular and biochemical techniques were used in the characterization of $P$. alba and other species of the section Algarobia (Saidman, 1985, 1986, 1988, 1990; Saidman and Vilardi, 1987, 1993; Keys and Smith, 1994; Verga, 1995; Saidman et al., 1997; Bessega et al., 2011, 2015, 2016). Although the presence of null alleles (David et al., 2007) may produce an artefactual upward bias in the $F_{\text {IS }}$ estimates, there is evidence indicating that the homozygote excess in the present work

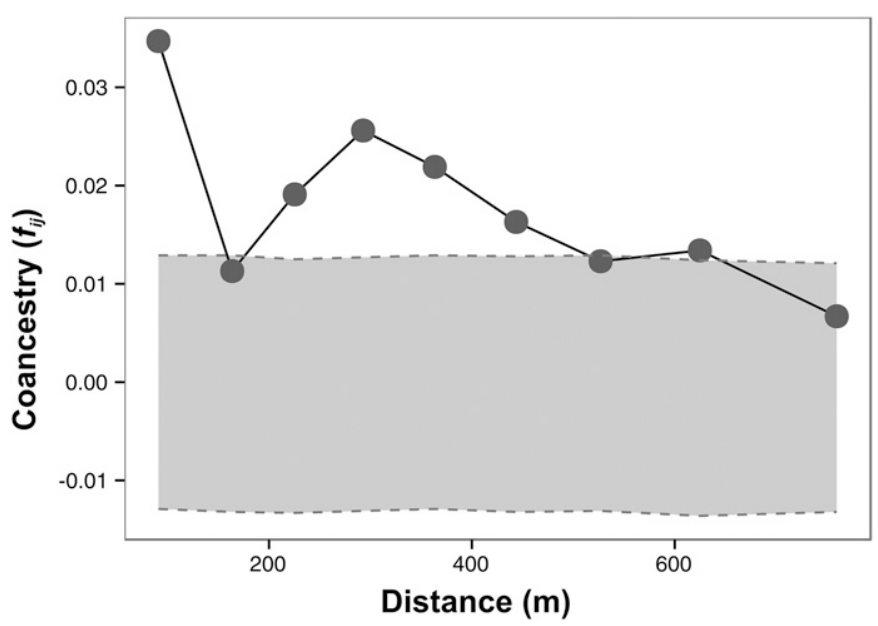

FIGURE 2 Correlogram of kinship vs. natural logarithm of the average geographical distance within classes. The area delimited between dotted lines represents the $95 \%$ confidence interval for the null hypothesis obtained under randomization. 


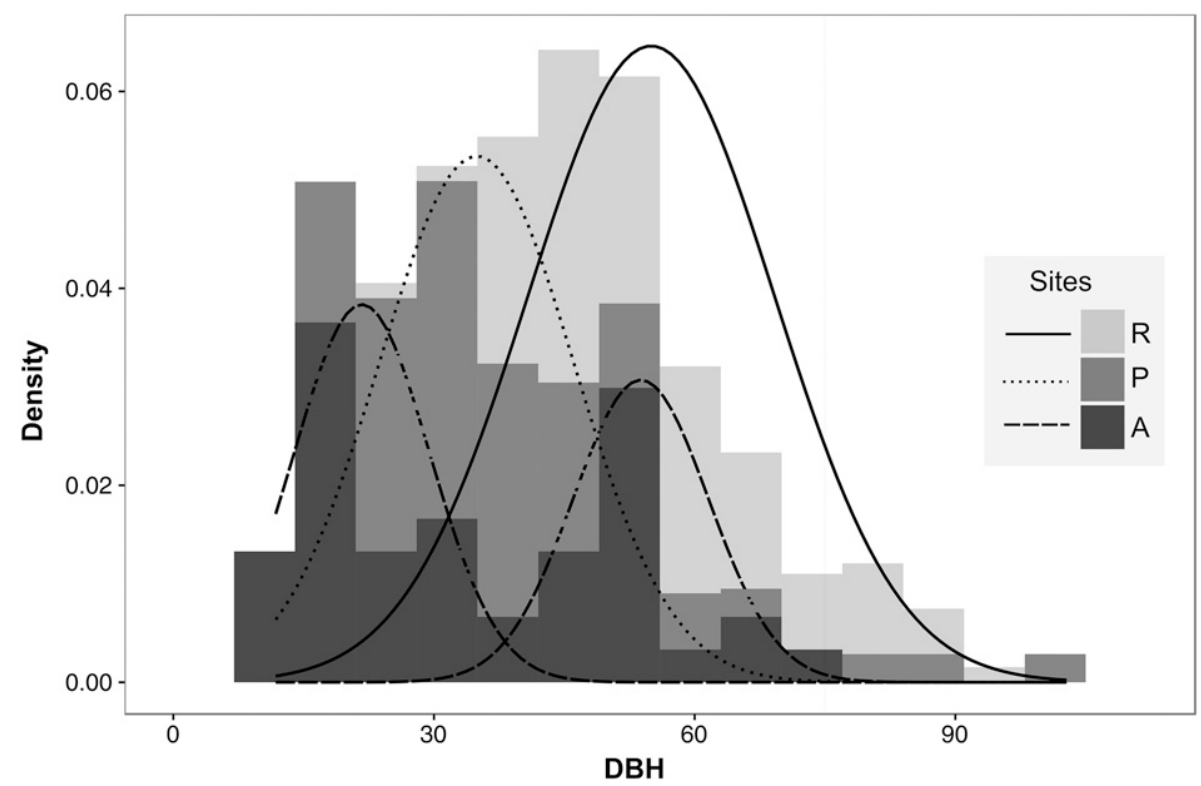

FIGURE 3 Histograms (density) of tree diameter at breast height ( $\mathrm{DBH}[\mathrm{cm}])$ for each of the considered sites ( $A, P$, and $R$ ). The Gaussian lines indicate the classes generated by the mixture model analysis.

cannot be explained only on the basis of null alleles: in the first place, an excess of homozygotes has been previously recorded in $P$. alba with other genetic markers; in the second place, the approach used in the present work was conservative, coding the homozygous state for the null allele as informative genotype; and finally, the kinship analysis showed that nearest neighbors, which are more likely to mate, are more related to each other than distant ones. Analyses of mating system and pollen dispersal in P. alba showed that this species is virtually $100 \%$ outcrossed; however, a low level (about 5\%) of biparental inbreeding occurs in the populations

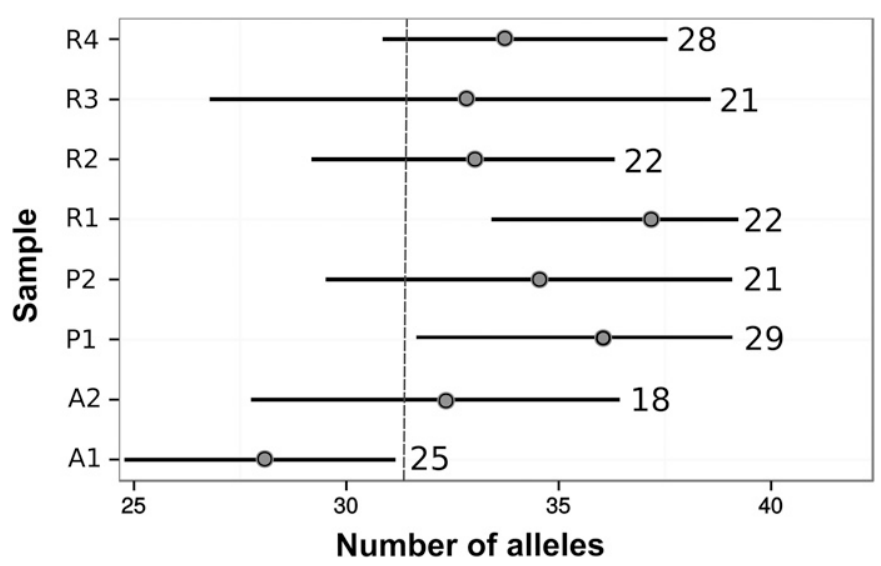

FIGURE 4 Observed values of allelic richness (gray circles) and confidence intervals (horizontal lines) for the DBH classes considered in the three sites of the demographic analysis, computed with a rarefacted sample size of $N=18$. Non-overlapping confidence intervals indicate significant differences at $95 \%$ level. Differentiation between pairs A1 and P1 and A1 and $\mathrm{R} 1$ is indicated by a dashed vertical line. The number at the right edge of each horizontal line indicates the sample size of the corresponding class.
(Bessega et al., 2000, 2012), which might partially explain the observed homozygote excess.

Previous research in section Algarobia of genus Prosopis found that most of the genetic variation is present within populations, with a relatively low differentiation contained between populations and species (Saidman, 1985; Saidman and Vilardi, 1987, 1993; Saidman et al., 1998; Bessega et al., 2000; Ferreyra et al., 2004, 2007, 2010, 2013). This genetic pattern was established as a general trend for long-lived woody, outcrossed, and late-successional species (Loveless and Hamrick, 1984; Hamrick et al., 1992). In concordance, the highest proportion of genetic variation in the population of this work was found within individuals (heterozygosity), while the rest was mainly represented by differentiation among individuals within sites, and a small proportion by differentiation among sites. The genetic differentiation among the three analyzed sites (A, P, and R) was significant by both Wright's $F_{\mathrm{ST}}$ and AMOVA approaches. In contrast, the Bayesian analysis with STRUCTURE did not show evidence to reject the existence of a common gene pool shared by the individuals of the whole population. The results of kinship analysis suggest that the outcomes of $\mathrm{AMOVA} / F_{\mathrm{ST}}$ and structure would be simply a consequence of isolation by distance. When an area is divided a priori into discrete zones, the gradual spatial change in allele frequencies that arise under IBD can promote these kind of combined results, i.e., an IBD pattern, as well as a hierarchical population structure (observed here through $F_{\mathrm{ST}}$ and AMOVA), even in the absence of any barrier to gene flow (Meirmans, 2012). The results may appear contradictory in scenarios such as the present, if the differentiation were explained in terms of Wahlund's (1928) effect, without taking into account the presence of IBD. This macroscale, gradual pattern promoted by IBD may be modulated by a microscale process of stochastic migration. A recent work comparing the genetic structure of two P. alba samples (Bessega et al., 2016) did not detect the presence of a clear pattern of SGS in a collection of trees located along a $9.4 \mathrm{~km}$ transect following National Route 34 (Santiago del Estero Province). Although the slope was significant for the relation between $f_{i j}$ and distance, the values of $f(d)$, including $f_{(1)}$, were all nonsignificant in the unidirectional correlogram. The methodology used in the present research, including a more extensive area with patches $\left(\sim 1361 \mathrm{~km}^{2}\right)$, and involving a higher number of samples to estimate both $f(d)$ and the regression slope $b$, allowed us to find an IBD pattern in the population, not detected in the survey of Bessega et al. (2016), where SGS was examined over a smaller spatial range. In that work, the observed absence of a significant kinship estimate for the first class of the correlogram $\left(f_{(1)}\right)$, would be due to a problem of scale, i.e., the number of trees with inter-individual distances included within the first class was small ( $<10$ trees).

SGS was also assessed by means of the $S p$ statistic, a normalized measure of the kinship decrease with the spatial distance between individuals. According to Vekemans and Hardy (2004), this parameter is related to life-forms, mating system and population 


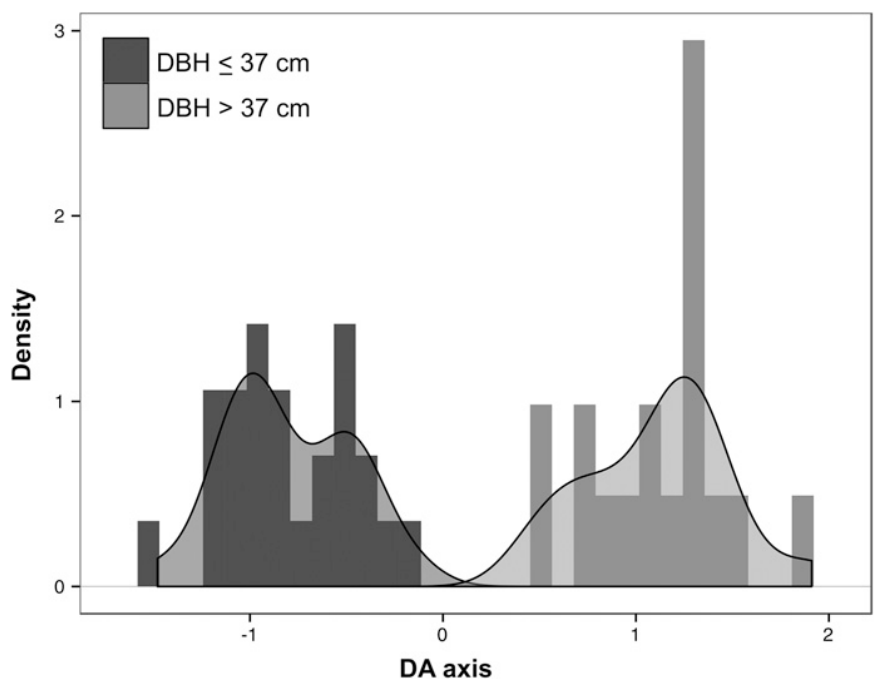

FIGURE 5 Histograms for the single axis obtained by discriminant analysis (DA), performed with the allele frequency matrix of site A. The two diameter classes are clearly separated.

density. The estimate of $S p$ obtained in the $P$. alba population $(0.0074)$ is close to the values found for other outcrossing trees where seed and pollen dispersal is also mediated by animals (reviewed by Vekemans and Hardy [2004] and Dick et al. [2008]). In contrast with the analysis performed by Bessega et al. (2016), the present $S p$ estimate was computed for a significant value of $f_{(1)}$. The kinship trend and the significant value of $S p$ suggest a sampling strategy for conservation that should take into account the pollination distance and the biparental inbreeding promoted by seed movements. A distance of $600 \mathrm{~m}$, as shown by the kinship analysis, would be enough to sample representative nonrelated individuals of the population.

The DBH histograms showed a bimodal distribution in site A, as confirmed by mixture modeling. These two groups of individuals with small and large $\mathrm{DBH}$, differ genetically, suggesting that at least two DBH cohorts occur in this site. In contrast, the other sites ( $\mathrm{P}$ and $\mathrm{R}$ ) showed unimodal distributions for $\mathrm{DBH}$ and genetic homogeneity among diameter classes. Furthermore, allelic richness was lower for the smallest trees of site A compared with sites $\mathrm{P}$ and $\mathrm{R}$. The lower allelic diversity at site A might be due to previous use of the patch for agricultural production, removal of most of the small trees, and presence of livestock. Relatively recent migration events mediated by livestock might have recruited individuals with a differentiated gene pool that does not represent all the genetic diversity in the source population. An expected result of this process is a loss of allelic richness and the generation of genetic structure in the sink population. Stochastic migration effects can have greater impact than the genetic drift inputs, especially when there are correlations or kinship relationships between the members of a migrant group (Epperson, 1993). The temporal consequences generated by thinning and migration over the SGS of the local population would become blurred with time (Tero et al., 2005). In summary, thinning and changes in migration patterns promoted by livestock introduction may have resulted in a preponderance of individuals with less variability than those originally established, causing a reduction in the genetic variation in the local gene pool.
The present work showed an overall IBD pattern in a population of $P$. alba, indicating that this species has been able to maintain the genetic cohesion in a fragmented area with land-use changes. Nevertheless, future works to comparatively assess the genetic structure in seeds and adults can give a better understanding of whether these observations also apply for more recent times, given the acceleration of the environmental degradation evidenced in the region (Gasparri and Grau, 2009). The results suggest that the genetic differentiation observed among sampling sites is a reflection of the prior division of the sample into clusters rather than an actual hierarchical structure. This example corroborates the theoretical perspective of Meirmans (2012) about the problematic use of standard statistical tests based on the nonspatial island model (Wright, 1931) in populations subject to IBD. The occurrence of a possible migration event detected in site A, suggests that stochastic processes operating on genetic variation at a microscale, may modulate the macroscale IBD pattern. The intensive sampling strategy applied in this research allowed us to detect the presence of IBD and migration that may remain hidden under other methodological approaches. Documentation of landscape genetic processes provides insights into the natural forces that shape the genetic variation within plant populations and contributes to the design of conservation strategies in threatened species.

\section{ACKNOWLEDGEMENTS}

This research was supported by funding from the Universidad de Buenos Aires (UBACYT 20020130100043BA), Agencia Nacional de Promoción Científica y Tecnológica (PICTO OTNA 00081 and PICT-2013 0478), and Consejo Nacional de Investigaciones Científicas y Técnicas (PIP N $\left.{ }^{\circ} 11220130100191 \mathrm{CO}\right)$ granted to B.O.S. and J.C.V. The authors acknowledge the Associate Editor and two anonymous reviewers for the numerous comments and suggestions, which contributed to a substantial improvement of the manuscript.

\section{LITERATURE CITED}

Adámoli, J., E. Sennhauser, J. Acero, and A. Rescia. 1990. Stress and disturbance: Vegetation dynamics in the dry Chaco region of Argentina. Journal of Biogeography 17: 491-500.

Arístide, P. 2010. Procesos históricos de cambio en la apropiación del territorio en Figueroa (Santiago del Estero, Argentina, Chaco semiárido). Ph.D. dissertation, Universidad Internacional de Andalucía, Andalucia, Spain.

Benjamini, Y., and Y. Hochberg. 1995. Controlling the false discovery rate: A practical and powerful approach to multiple testing. Journal of the Royal Statistical Society, B, Methodological 57: 289-300.

Bessega, C., L. Ferreyra, N. Julio, S. Montoya, B. Saidman, and J. Vilardi. 2000. Mating system parameters in species of genus Prosopis (Leguminosae). Hereditas 132: 19-27.

Bessega, C., C. Pometti, M. Ewens, B. Saidman, and J. Vilardi. 2012. Strategies for conservation for disturbed Prosopis alba (Leguminosae, Mimosoidae) forests based on mating system and pollen dispersal parameters. Tree Genetics \& Genomes 8: 277-288.

Bessega, C., C. Pometti, M. Ewens, B. Saidman, and J. Vilardi. 2015. Improving initial trials in tree breeding using kinship and breeding values estimated in the wild: The case of Prosopis alba in Argentina. New Forests 46: 427-448.

Bessega, C., C. Pometti, J. Miller, R. Watts, B. Saidman, and J. Vilardi. 2013. New microsatellite loci for Prosopis alba and P. chilensis (Fabaceae). Applications in Plant Sciences 1(5). 
Bessega, C., B. Saidman, M. Darquier, M. Ewens, P. Felker, and J. Vilardi. 2011 Accuracy of dominant markers for estimation of relatedness and heritability in an experimental stand of Prosopis alba (Leguminosae). Tree Genetics \& Genomes 7: 103-115.

Bessega, C., C. Pometti, M. Ewens, B. Saidman, and J. Vilardi. 2016. Finescale spatial genetic structure analysis in two Argentine populations of Prosopis alba (Mimosoideae) with different levels of ecological disturbance. European Journal of Forest Research 135: 495-505.

Chessel, D., A. Dufour, and J. Thioulouse. 2004. The ade4 package-I-One-table methods. $R$ News 4: 5-10.

Chung, M. Y., J. Nason, B. Epperson, and M. G. Chung. 2003. Temporal aspects of the fine-scale genetic structure in a population of Cinnamomum insularimontanum (Lauraceae). Heredity 90: 98-106.

David, P., B. Pujol, F. Viard, V. Castella, and J. Goudet. 2007. Reliable selfing rate estimates from imperfect population genetic data. Molecular Ecology 16: 2474-2487.

Dempster, A., N. Laird, and D. Rubin. 1977. Maximum likelihood from incomplete data via the EM algorithm. Journal of the Royal Statistical Society, B, Methodological 39: 1-38.

Dick, C., O. Hardy, F. Jones, and R. Petit. 2008. Spatial scales of pollen and seed-mediated gene flow in tropical rain forest trees. Tropical Plant Biology 1: 20-33.

Dray, S., and A. Dufour. 2007. The ade4 package: Implementing the duality diagram for ecologists. Journal of Statistical Software 22: 1-20.

Earl, D., and B. vonHoldt. 2012. STRUCTURE HARVESTER: A website and program for visualizing STRUCTURE output and implementing the Evanno method. Conservation Genetics Resources 4: 359-361.

Epperson, B. 1993. Recent advances in correlation studies of spatial patterns of genetic variation. Evolutionary Biology 27: 95-155.

Evanno, G., S. Regnaut, and J. Goudet. 2005. Detecting the number of clusters of individuals using the software STRUCTURE: A simulation study. Molecular Ecology 14: 2611-2620.

Falush, D., M. Stephens, and J. Pritchard. 2003. Inference of population structure using multilocus genotype data: Linked loci and correlated allele frequencies. Genetics 164: 1567-1587.

Fenster, C., X. Vekemans, and O. Hardy. 2003. Quantifying gene flow from spatial genetic structure data in a metapopulation of Chamaecrista fasciculata (Leguminosae). Evolution 57: 995-1007.

Ferreyra L., C. Bessega, J. Vilardi, and B. Saidman. 2004. First report on RAPDs patterns able to differentiate some Argentinean species of section Algarobia (Prosopis, Leguminosae). Genetica 121: 33-42.

Ferreyra, L., C. Bessega, J. Vilardi, and B. Saidman. 2007. Consistency of population genetics parameters estimated from isozyme and RAPDs dataset in species of genus Prosopis (Leguminosae, Mimosoideae). Genetica 131: 217-230.

Ferreyra, L., J. Vilardi, D. Tosto, N. Julio, and B. Saidman. 2010. Adaptive genetic diversity and population structure of the "algarrobo"[Prosopis chilensis (Molina) Stuntz] analysed by RAPD and isozyme markers. European Journal of Forest Research 129: 1011-1025.

Ferreyra, L., J. Vilardi, A. Verga, V. López, and B. Saidman. 2013. Genetic and morphometric markers are able to differentiate three morphotypes belonging to Section Algarobia of genus Prosopis (Leguminosae, Mimosoideae). Plant Systematics and Evolution 299: 1157-1173.

Finkeldey, R., and G. Mátyás. 2003. Genetic variation of oaks (Quercus spp.) in Switzerland. 3. Lack of impact of postglacial recolonization history on nuclear gene loci. Theoretical and Applied Genetics 106: 346-352.

Fraley, C., and A. Raftery. 2002. Model-based clustering, discriminant analysis and density estimation. Journal of the American Statistical Association 97: 611-631.

Gasparri, N., and H. Grau. 2009. Deforestation and fragmentation of Chaco dry forest in NW Argentina (1972-2007). Forest Ecology and Management 258: 913-921.

Genise, J., R. Palacios, P. Hoc, R. Carrizo, L. Moffat, M. Mom, M. Agullo, L. Agullo, P. Picca, and S. Torregrosa. 1990. Observaciones sobre la biología floral de Prosopis (Leguminosae, Mimosoideae). II. Fases florales y visitantes en el Distrito Chaqueño Serrano. Darwiniana 30: 71-85.
Giménez, A., N. Ríos, G. Moglia, P. Hernández, and S. Bravo. 2001. Estudio de magnitudes dendrométricas en función de la edad en Prosopis alba Griseb., algarrobo blanco, Mimosaceae. Revista Forestal Venezolana 45: 175-183.

Goudet, J. 2005. HIERFSTAT, a package for R to compute and test hierarchical F-statistics. Molecular Ecology Notes 5: 184-186.

Hamrick, J., M. Godt, and S. Sherman-Broyles. 1992. Factors influencing levels of genetic diversity in woody plant species. New Forests 6: 95-124.

Hamrick, J., D. Murawski, and J. Nason. 1993. The influence of seed dispersal mechanisms on the genetic structure of tropical tree populations. In $\mathrm{E}$. Fleming and A. Estrada [eds.], Frugivory and seed dispersal: Ecological and evolutionary aspects, 281-297. Kluwer, Dordrecht, Netherlands.

Hardy, O., L. Maggia, E. Bandou, P. Breyne, H. Caron, M.-H. Chevallier, A. Doligez, et al. 2006. Fine-scale genetic structure and gene dispersal inferences in 10 Neotropical tree species. Molecular Ecology 15: 559-571.

Hardy, O., and X. Vekemans. 2015. SPAGeDi 1.5. A program for Spatial Pattern Analysis of Genetic Diversity. User's manual http://ebe.ulb.ac.be/ebe/ SPAGeDi_files/SPAGeDi_1.5_Manual.pdf. Université Libre de Bruxelles, Brussells, Belgium.

Heuertz, M., X. Vekemans, J.-F. Hausman, M. Palada, and O. Hardy. 2003. Estimating seed vs. pollen dispersal from spatial genetic structure in the common ash. Molecular Ecology 12: 2483-2495.

Juárez de Galíndez, M., A. Giménez, N. Ríos, and M. Balzarini. 2005. Modelación de crecimiento en Prosopis alba Griseb. empleando dos modelos biológicos. Quebracho 12: 34-42.

Kamvar, Z., J. Tabima, and N. Grünwald. 2014. Poppr: An R package for genetic analysis of populations with clonal, partially clonal, and/or sexual reproduction. PeerJ 2: e281.

Keenan, K., P. McGinnity, T. Cross, W. Crozier, and P. Prodöhl. 2013. diveRsity: An R package for the estimation of population genetics parameters and their associated errors. Methods in Ecology and Evolution 4: 782-788.

Kalinowski, S. 2004. Counting alleles with rarefaction: Private alleles and hierarchical sampling designs. Conservation Genetics 5: 539-543.

Kalisz, S., J. Nason, F. Hanzawa, and S. Tonsor. 2001. Spatial population genetic structure in Trillium grandiflorum: The roles of dispersal, mating, history, and selection. Evolution 55: 1560-1568.

Keys, R., and S. Smith. 1994. Mating system parameters and population genetic structure in pioneer populations of Prosopis velutina (Leguminosae). American Journal of Botany 81: 1013-1020.

Kottek, M., J. Grieser, C. Beck, B. Rudolf, and F. Rubel. 2006. World map of the Köppen-Geiger climate classification updated. Meteorologische Zeitschrift 15: 259-263.

Levin, D., and H. Kerster. 1974. Gene flow in seed plants. Evolutionary Biology 7: 139-220.

Loiselle, B., V. Sork, J. Nason, and C. Graham. 1995. Spatial genetic structure of a tropical understory shrub, Psychotria officinalis (Rubiaceae). American Journal of Botany 82: 1420-1425.

Loveless, M., and J. Hamrick. 1984. Ecological determinants of genetic structure in plant populations. Annual Review of Ecology, Evolution and Systematics 15: 65-95.

Malécot, G. 1948. Mathématiques de l'hérédité. Masson et Cie, Paris, France.

Malécot, G. 1959. Les modeles stochastiques en genetique de population. Publications de L'Institut de Statistiques de l'Université de Paris 8: 173-210.

Mares, M., F. Enders, J. Kingsolver, J. Neff, and B. Simpson. 1977. Prosopis as a niche component. In B. Simpson [ed.], Mesquite: Its biology in two desert scrub ecosystems, 123-149. Hutchinson \& Ross, Stroudsburg, Pennsylvania, USA.

Meirmans, P. 2012. The trouble with isolation by distance. Molecular Ecology 21: 2839-2846.

Michalakis, Y., and L. Excoffier. 1996. A generic estimation of population subdivision using distances between alleles with special reference for microsatellite loci. Genetics 142: 1061-1064.

Morton, N., C. Miki, and S. Yee. 1968. Bioassay of population structure under isolation by distance. American Journal of Human Genetics 20: 411.

Mottura, M., R. Finkeldey, A. Verga, and O. Gailing. 2005. Development and characterization of microsatellite markers for Prosopis chilensis and Prosopis flexuosa and cross-species amplification. Molecular Ecology Notes 5: 487-489. 
Nei, M., and R. Chesser. 1983. Estimation of fixation indices and gene diversities. Annals of Human Genetics 47: 253-259.

Pardini, E., and J. Hamrick. 2008. Inferring recruitment history from spatial genetic structure within populations of the colonizing tree Albizia julibrissin (Fabaceae). Molecular Ecology 17: 2865-2879.

Parker K., J. Hamrick, A. Parker, and J. Nason. 2001. Fine-scale genetic structure in Pinus clausa (Pinaceae) populations: Effects of disturbance history. Heredity 87: 99-113.

Pasiecznik, N., P. Felker, P. Harris, L. Harsh, G. Cruz, J. Tewari, et al. 2001. The Prosopis juliflora-Prosopis pallida complex: A monograph. Henry Doubleday Research Association, Coventry, UK.

Premoli, A., and T. Kitzberger. 2005. Regeneration mode affects spatial genetic structure of Nothofagus dombeyi forests. Molecular Ecology 14: 2319-2329.

Pritchard, J., M. Stephens, and P. Donnelly. 2000. Inference of population structure using multilocus genotype data. Genetics 155: 945-959.

R Core Team. 2014. R: A language and environment for statistical computing. R Foundation for Statistical Computing, Vienna, Austria.

Reynolds, H. 1954. Some interrelations of the Merriam kangaroo rat to velvet mesquite. Journal of Range Management 7: 176-180.

Rousset, F. 1997. Genetic differentiation and estimation of gene flow from Fstatistics under isolation by distance. Genetics 145: 1219-1228.

Rousset, F. 2000. Genetic differentiation between individuals. Journal of Evolutionary Biology 13: 58-62.

Rousset, F. 2008. GENEPOP'007: A complete reimplementation of the GENEPOP software for Windows and Linux. Molecular Ecology Resources 8: 103-106.

Roser, L., L. Ferreyra, M. Ewens, J. Vilardi, and B. Saidman. 2014. Genetic and morphometric characterization of clones of Prosopis alba, Algarobia, selected for salt tolerance. Tree Genetics \& Genomes 10: 383-397.

Roser, L., J. Vilardi, B. Saidman, and L. Ferreyra. 2015. EcoGenetics: Spatial analysis of phenotypic, genotypic and environmental data. $\mathrm{R}$ package version 1.2.0-3. Website https://cran.r-project.org/web/packages/ EcoGenetics.

Saidman, B. 1985. Estudio de la variación alozímica en el género Prosopis. Estudio de La variación alozímica en el género Prosopis. Ph.D. dissertation, Universidad de Buenos Aires, Buenos Aires, Argentina.

Saidman, B. 1986. Isoenzymatic studies of alcohol dehydrogenase and glutamate oxalacetate transaminase in four South American species of Prosopis and their natural hybrids. Silvae Genetica 35: 3-10.

Saidman, B. 1988. La electroforesis de isoenzimas para la medición de la variabilidad genética en especies de Prosopis. In FAO-PIRB [eds.], Prosopis en Argentina, 107-118. Facultad de Ciencias Agrarias, Universidad Nacional de Córdoba, Córdoba, Argentina.

Saidman, B. 1990. Isozyme studies on hybrid swarms of Prosopis caldenia and sympatric species. Silvae Genetica 39: 5-8.
Saidman, B., and J. Vilardi. 1987. Analysis of the genetic similarities among seven species of Prosopis (Leguminosae: Mimosoideae). Theoretical and Applied Genetics 75: 109-116.

Saidman, B., and J. Vilardi. 1993. Genetic variability and germplasm conservation in the genus Prosopis, 187-198. Winrock-Oxford \& IBH Publishing, New Delhi, India.

Saidman, B., J. Vilardi, S. Montoya, M. Dieguez, H. Hopp, and S. Puri. 1998. Molecular markers: A tool for understanding the relationship among species of Prosopis (Leguminosae, Mimosoideae). In S. Puri [ed.], Tree improvement: Applied research and technology transfer, 311-324. Science Publishers, Enfield, New Hampshire, USA.

Saidman, B., J. Vilardi, S. Montoya, and L. Poggio. 1997. Genetic variability and ploidy level in species of Prosopis (Leguminosae, Mimosoideae). Boletín de la Sociedad Argentina de Botánica 32: 217-225.

Smouse, P., and R. Peakall. 1999. Spatial autocorrelation analysis of individual multiallele and multilocus genetic structure. Heredity 82: 561-573.

Sokal, R., and F. Rohlf. 1981. Biometry. W. H. Freeman, San Francisco, California, USA.

Sokal, R., and D. Wartenberg. 1983. A test of spatial autocorrelation analysis using an isolation-by-distance model. Genetics 105: 219-237.

Steibel, P., and H. Troiani. 1999. El género Prosopis (Leguminosae) en la provincia de La Pampa. Revista de la Facultad de Agronomía. Universidad Nacional de La Pampa 10: 25-48.

Tero, N., J. Aspi, P. Siikamäki, and A. Jäkäläniemi. 2005. Local genetic population structure in an endangered plant species, Silene tatarica (Caryophyllaceae). Heredity 94: 478-487.

Torrella, S., and J. Adámoli. 2005. Situación ambiental de la ecorregión del Chaco Seco. In A. Brown, U. Martínez Ortiz, M. Acerbi, and J. Corcuera [eds.], La situación ambiental Argentina, 5-82. Fundación Vida Silvestre Argentina, Buenos Aires, Argentina.

Van Loon, E., D. Cleary, and C. Fauvelot. 2007. ARES: Software to compare allelic richness between uneven samples. Molecular Ecology Notes 7: 579-582.

Verga A. 1995. Genetische untersuchungen an Prosopis chilensis und Prosopis flexuosa (Mimosaceae) im trockenen Chaco Argentiniens. Göttingen Research Notes in Forest Genetics 19: 1-16.

Vekemans, X., and O. Hardy. 2004. New insights from fine-scale spatial genetic structure analyses in plant populations. Molecular Ecology 13: 921-935.

Wahlund, S. 1928. The combination of populations and the appearance of correlation examined from the standpoint of the study of heredity. Hereditas 11: 65-106.

Weir, B., and C. Cockerham. 1984. Estimating F-statistics for the analysis of population structure. Evolution 38: 1358-1370.

Wright, S. 1931. Evolution in Mendelian populations. Genetics 16: 97-159.

Wright, S. 1943. Isolation by distance. Genetics 28: 114 .

Wright, S. 1951. The genetical structure of populations. Annals of Eugenics 15: 323-354.

\section{APPENDIX 1 Information on voucher specimens of Prosopis alba used in this study.}

Prosopis alba Griseb: collection site Santiago del Estero, Argentina, $27^{\circ} 51^{\prime} 5.70^{\prime \prime} \mathrm{S}, 64^{\circ} 10^{\prime} 23.76^{\prime \prime} \mathrm{W}$; collector L. Roser; voucher speci- mens LGR001-LGR186, Buenos Aires BAFC herbarium (Universidad de Buenos Aires, Facultad de Ciencias Exactas y Naturales). 